\title{
Persepsi atlet pelajar: tingkah laku kejurulatihan sukan balapan dan padang
}

\begin{abstract}
ABSTRAK
Dalam konteks mendalami pengetahuan kejurulatihan dalam sukan di Malaysia khususnya di Sarawak, kajian ini bertujuan untuk mengkaji persepsi atlet pelajar terhadap tingkah laku kejurulatihan, di samping mengenal pasti tingkah laku kejurulatihan yang diingini oleh atlet pelajar serta tingkah laku yang sedia ada pada kejurulatihan sukan balapan dan padang negeri Sarawak. Kajian ini merupakan kajian deskriptif yang menggunakan kaedah persampelan rawak berstrata mengikut saiz kumpulan sama (equal-size groups in stratified sampling). Responden kajian terdiri daripada 252 orang atlet pelajar sekolah menengah (lelaki, $\mathrm{n}=126$; perempuan, $\mathrm{n}=126$ ) yang berumur 13 hingga 18 tahun dan pernah mewakili bahagian masing-masing dalam pertandingan. Soal selidik Skala Kepimpinan untuk Sukan (LSS) yang dibangunkan oleh Chelladurai dan Saleh (1980) telah diadaptasi dan digunakan sebagai intrumen kajian untuk mengukur 5 tingkah laku kejurulatihan. Berdasarkan persepsi atlet pelajar sukan balapan dan padang Sarawak terhadap tingkah laku kejurulatihan, didapati bahawa tingkah laku yang dingini oleh atlet pelajar adalah sama dengan tingkah laku kejurulatihan yang sedia ada pada jurulatih. Kajian mendapati bahawa tingkah laku yang diingini oleh atlet pelajar mengikut keutamaan adalah tingkah laku Arahan dan Latihan $(\mathrm{M}=$ 4.33, SP = 0.67), diikuti oleh tingkah laku Maklum Balas Positif $(\mathrm{M}=4.14, \mathrm{SP}=0.74)$. Dapatan persepsi atlet pelajar terhadap tingkah laku yang kerap sedia ada pada jurulatih pula adalah tingkah laku arahan dan latihan $(\mathrm{M}=4.13, \mathrm{SP}=0.68)$, diikuti tingkah laku maklum balas positif $(\mathrm{M}=3.89$, $\mathrm{SP}=0.75)$. Secara kesimpulannya, didapati bahawa persepsi atlet terhadap tingkah laku kejurulatihan adalah tidak berbeza dari segi jantina, kedua-dua atlet lelaki dan perempuan menyatakan pandangan yang serupa dalam tingkah laku kejurulatihan yang diingini dan tingkah laku kejurulatihan yang sedia ada pada jurulatih, iaitu tingkah laku Arahan dan Latihan.
\end{abstract}

Keyword: Preferred coaching behavior; Perceived coaching behavior; Coaching style; Athlete perception 